\title{
Nutritional, functional and microbiological characteristics of Jordanian fermented green Nabali Baladi olives
}

\author{
${ }^{\oplus}$ M.N. Ahmad ${ }^{\bowtie}$, ${ }^{-G}$ G.F. Mehyar and ${ }^{\oplus}$ G.A. Othman \\ Department of Nutrition and Food Technlolgy. University of Jordan, Amman 11942, Jordan \\ ${ }^{\bowtie}$ Corresponding author: mosnuman@ju.edu.jo
}

Submitted: December 21, 2019; Accepted: February 21, 2020; Published online: February 24, 2021

\begin{abstract}
SUMMARY: The quality characteristics of green olives produced by the traditional spontaneous fermentation method in Jordan have never been studied. We investigated the nutritional, functional, and microbiological characteristics of Jordanian fermented green Nabali Baladi olives (GNBFO). Proximate composition, fatty acids, and total polyphenols were determined by standard protocols. Cultivable microflora was monitored over 3 months of fermentation. Isolated microorganisms were identified by molecular sequencing and in vitro probiotic traits were tested. GNBFO contained fiber $(3 \mathrm{~g} / 100 \mathrm{~g})$, total polyphenols $(306 \mathrm{mg} / 100 \mathrm{~g})$, oil $(19.3 \mathrm{~g} / 100 \mathrm{~g})$, and oleic acid $(70 \%)$. Yeast strains (Candida diddensiae and Candida naeodendra) were predominant and showed acid $(\mathrm{pH}=2.5)$ and bile salt $(0.1 \%$ and $0.3 \%)$ resistant and high adhesion ability (ca $\left.\sim 10^{7} \mathrm{CFU} / \mathrm{ml}\right)$ to intestinal cell lines; they were positive to catalase and negative to lipase and none possessed antimicrobial activity against selected pathogens. Lactic acid bacteria were not detected. In conclusion, the GNBFO have promising functional characteristics as they contain valuable nutrients, antioxidants, and yeast strains with potential probiotic traits.
\end{abstract}

KEYWORDS: Oleic Acid; Olive; Polyphenols; Probiotics; Spontaneous Fermentation; Yeast

RESUMEN: Características nutricionales, funcionales y microbiológicas de las aceitunas verdes jordanas fermentadas Nabali Baladi. Hasta la fecha, no se han estudiado las características de calidad de las aceitunas verdes producidas por el método tradicional de fermentación espontánea en Jordania. En este trabajo, investigamos las características nutricionales, funcionales y microbiológicas de las aceitunas Nabali Baladi verdes fermentadas jordanas (GNBFO). La composición proximal, los ácidos grasos y los polifenoles totales se determinaron mediante protocolos estándar. La microflora cultivable se controló durante 3 meses de fermentación. Se identificaron microorganismos aislados por secuenciación molecular y se probaron los rasgos probióticos in vitro. GNBFO contenía fibra $(3 \mathrm{~g} / 100 \mathrm{~g})$, polifenoles totales $(306 \mathrm{mg} / 100 \mathrm{~g})$, aceite $(19,3 \mathrm{~g} / 100 \mathrm{~g})$ y ácido oleico $(70 \%)$. Las cepas de levaduras (Candida diddensiae y Candida naeodendra) fueron predominantes y mostraron acidez $(\mathrm{pH}=2.5)$ y sales biliares $(0,1 \%$ y $0,3 \%)$ resistentes y alta capacidad de adhesión $\left(\mathrm{ca} \sim 10^{7} \mathrm{CFU} / \mathrm{ml}\right)$ a las líneas celulares intestinales; fueron positivos para catalasa y negativos para lipasa y ninguno poseía actividad antimicrobiana contra patógenos seleccionados. No se detectaron bacterias del ácido láctico. En conclusión, GNBFO tiene características funcionales prometedoras, ya que contienen valiosos nutrientes, antioxidantes y cepas de levaduras con posibles rasgos probióticos.

PALABRAS CLAVE: Ácido Oleico; Fermentación Espontánea; Levadura; Oliva; Polifenoles; Probióticos

Citation/Cómo citar este artículo: Ahmad MN, Mehyar GF, Othman GA. 2021. Nutritional, functional and microbiological characteristics of Jordanian fermented green Nabali Baladi olives. Grasas Aceites 72 (1), e396. https://doi.org/10.3989/gya.1258192

Copyright: (C2021 CSIC. This is an open-access article distributed under the terms of the Creative Commons Attribution 4.0 International (CC BY 4.0) License. 


\section{INTRODUCTION}

The olive (Olea europaea L.) is an ancient cultivated human plant food. It originates in the Middle East and the Mediterranean region and is central to the local diet (Al-Ismail et al., 2011; Ghanbari et al., 2012). Despite the global spread of olive cultivation, most of its production comes from the Mediterranean basin, (Ghanbari et al., 2012). In Jordan, almost $80 \%$ of the olives are used for oil production and 20\% for fermentation to produce table olives (MOA, 2016). In 2016, table olive consumption in Jordan reached 28 thousand tons (MOA, 2016). Consumption of olives is related to higher-quality diets, including higher intakes of dietary fiber, proteins, a number of vitamins, mineral elements, phenolic compounds, organic acids, pigments, and phytosterols, monounsaturated oleic acid, and lower intakes of saturated fat (López et al., 2007; Ghanbari et al., 2012). These components are known to possess multiple biological, medicinal, and therapeutic effects such as antioxidant, antihyperlipidemic, antimicrobial, antiinflammation, antihypertensive, anticarcinogenic, and antithrombotic (Lanza et al., 2010). In essence, the intake of olives and their oil is associated with several health benefits, particularly reduced risks of cardiovascular disease, insulin resistance, and cancer (Saibandith et al., 2017). Nevertheless, the salt content in table olives greatly varies depending on the preparation process (López et al., 2008), a matter that may represent a health concern. This is especially important in populations which consume high amounts of olives and subsequently salt, because of its association with hypertension (Pino et al., 2018).

The olive's functional nutrients, bioactive, and health-promoting components have been shown to vary greatly with olive genotype, maturity, product quality, postharvest handling and storage conditions, agricultural practices, and methods of processing and analysis (Bleve et al., 2014). Worldwide, about two thousand olive varieties have been identified (Ghanbari et al., 2012); several of these varieties inhabit Jordan, mainly Nabali Baladi, Muhasan, Rassei, Shami and Nasohi (Al-Ismail et al., 2011). The Nabali olive is the major olive genotype grown in Jordan and is widely used in traditional fermentation and oil production as it is naturally adapted to the dry conditions in Jordan and provides a high oil yield (Humeid et al., 1991). In fact, the available literature on the nutritional and health benefits of olives and olive oil is basically derived from results of studies investigating olive varieties other than those grown in Jordan (Lanza et al., 2010; Aponte et al., 2010; Issaoui et al., 2011).

Furthermore, a number of technological methods to produce table olives are available (Issaoui et al., 2011) and yield olives with varied chemical and microbiological characteristics (Abriouel et al., 2011). These methods of olive fermentation greatly influence the competitive activities of the natural microflora that lead to spontaneous fermentation (Abriouel et al., 2011). Several Lactic acid bacteria (LAB) and yeast species are the main natural microbes engaged in olive fermentation (Bleve et al., 2014). In Jordan and eastern Mediterranean countries, the traditional fermentation method of green olives depends on spontaneous fermentation in high brine concentration after debittering the green olives by soaking in water for 3 days (NCARE, 2000). This method results in fermented olives with a unique sour taste that differs remarkably from Greek, Italian or Spanish methods. To the best of our knowledge, the nutritional, functional and microbiological characteristics of the fermented Nabali olive have not yet been elucidated. Hence, this study was performed to identify some of such characteristics of table olives produced by the traditional fermentation method in Jordan.

\section{MATERIALS AND METHODS}

\subsection{Olives fermentation}

Green Nabali Baladi olives (15 kg) were purchased from a local farm in Jerash, Jordan, in two successive seasons (November 2017 and November 2018) and processed according to the traditional method of green olive fermentation in Jordan (NCARE, 2000). Olives of each season were crushed under mechanical pressure to make a scratch in the flesh, soaked in water for three days, placed in two glass jars and the brine solution $(10 \% \mathrm{wt} / \mathrm{vol})$ was added. The brined olives were kept in a dark, dry place at room temperature $\left(17-20{ }^{\circ} \mathrm{C}\right)$ to allow natural fermentation to take place (NCARE, 2000). The fermentation lasted 3 months. 


\subsection{Microbiological analysis}

A $30 \mathrm{~g}$ sample of olive flesh was taken from each jar after 30, 60 and 90 days of fermentation. Samples were washed with sterile saline $(0.9 \%$ $\mathrm{NaCl} \mathrm{wt} / \mathrm{vol})$ solution $(30 \mathrm{ml})$ and homogenized by a Stomacher lab blender (Bag Mixer ${ }^{\circledR} 400 \mathrm{~W}$, Interscience, France). A $10 \mathrm{~g}$ sample of the homogenized olive paste was diluted with $90 \mathrm{ml}$ peptone water, and then 10-fold serial dilution was carried out. Lactic acid bacteria (LAB) and yeasts were quantified as follows: samples of $100 \mu 1$ of each dilution were applied to agar plates that contained Man, Rogosa and Sharpe Agar (MRS, Oxoid, England), followed by anaerobic incubation at $30^{\circ} \mathrm{C}$ for $48-72$ hours (Bleve et al., 2014) and Potato Dextrose Agar (Oxoid, England) supplemented with chloramphenicol and chlortetracycline (Dar Al Dawa, Amman, Jordan), followed by incubation at $25{ }^{\circ} \mathrm{C}$ for $2-4$ days (FDA, 2001). Gram staining and viable counts were performed to identify the isolated microorganisms. The $\mathrm{pH}$ of the brine solution was measured (Hanna Instrument, USA). Analysis of brine concentration was also performed by using Mohr's titration method (AOAC, 1995). The experiments were performed in triplícate.

\subsection{Analysis of proximate composition}

A proximate composition analysis was performed on the fermented olives according to the reference Weende method (AOAC 1995). For moisture content determination, samples of olive pulp were dried at $105{ }^{\circ} \mathrm{C}$ using the air oven (Memmert, Karlklob-West Germany) until a constant weight was reached. The dried olive pulp was used to determine the fat content following the solvent (ether $40-70{ }^{\circ} \mathrm{C}$ ) extraction procedure for 6 hours using the Soxhlet apparatus. The ether was evaporated and the residual oil was then weighed (AOAC, 1995). Crude protein in the pulp of the dried olives was measured using the micro Kjeldahl method (AOAC, 1995). The preweighed samples of olives were digested in $10 \mathrm{ml}$ sulfuric acid in the presence of catalyst tablets containing $\mathrm{K}_{2} \mathrm{SO}_{4}, \mathrm{CuSO}_{4}$, and selenium. The reduced ammonia was liberated by boiling with $50 \%$ sodium hydroxide and distilled (Rapid Distillation Unit, Lanconco Corporation, Kansas City, USA) into a boric acid solution to form ammonia borate that was titrated directly using a standard sulfuric acid solution. The resultant nitrogen content was multiplied by the factor 6.25 to determine the crude protein content.
Crude ash was analyzed by the dry ashing method (AOAC, 1995). The pre-weighed samples were ignited in a muffle furnace (Naber Model D2804, Bremen) at $550{ }^{\circ} \mathrm{C}$ for 6 hours. The inorganic ash residue was then weighed. The crude fiber of dried and defatted olive pulp was determined according to the Van Soest method (AOAC, 1995). In pre-weighed filter bags, a sample of $1 \mathrm{~g}$ of dried and defatted olives was weighed. The sample-containing bag was sealed and placed in the bag suspender trays of the fiber analyzer (ANKOM, USA). The sample was digested using a standard sulfuric acid solution $(1.25 \%)$ for 30 minutes, and then in a sodium hydroxide solution $(1.25 \%)$ for 30 minutes. The bags were then dried in an air oven at $105^{\circ} \mathrm{C}$ and cooled before weighing. The sample-containing bag was ashed in pre-weighed crucibles for 2 hours at $550{ }^{\circ} \mathrm{C}$, cooled in a desiccator, and then weighed. The crude fiber content was calculated by subtracting the weight before and after ashing (AOAC, 1995). The carbohydrate content of olive pulp was estimated as the resulting difference from subtracting the content of each of moisture, protein, fat, ash, and fiber from $100 \%$ (Bleve et al., 2014).

\subsection{Analysis of fatty acid composition}

The extraction of fat from fermented olives was performed according to Issaoui et al., (2011). The olive pulp was well ground to form a paste from which fat was extracted using a methanol/water/ chloroform $(1 / 1 / 1 ; \mathrm{v} / \mathrm{v} / \mathrm{v})$ solvent mixture. The fat-containing mixture was centrifuged, the solvent layer was evaporated at $60^{\circ} \mathrm{C}$, and the EC Regulation no. 2568/91 method was used to prepare the fatty acid methyl esters. In brief, a pre-weighed sample of fat extract $(50 \mathrm{mg})$ was well mixed with hexane ( $2 \mathrm{ml}, \mathrm{GC}$ grade) and a freshly-prepared solution $(200 \mu \mathrm{l})$ made up of 2 M-potassium hydroxide in anhydrous methanol was added and thoroughly mixed to form a clear solution, and then acetic acid $(200 \mu 1)$ was added with continuous mixing. Soon after esterification was complete, the capillary GC column (Restek, Rtx-225, USA, cross bond 50\%-cyanopropylmethyl 50\%-phenylmethyl polysilo-xane, $60 \mathrm{~m}$, $0.25 \mu \mathrm{m} / \mathrm{D}, 0.25 \mu \mathrm{m} \mathrm{df}$ ) was used to determine the fatty acid methyl esters. The latter was identified using the chromatogram of the corresponding fatty acid methyl ester standards (Supelco Inc, Bellefonte, USA) as described elsewhere (Al-Ismail et al., 2011). 


\subsection{Analysis of total polyphenols}

The Folin-Ciocalteu assay was used to quantify the total polyphenols in olive pulp. The method is essentially based on the ability of phenols to reduce phosphomolybdic acid in aqueous alkali media. Methanol solvent was used to extract ( 3 times) olive pulp $(5 \mathrm{~g})$ and $(0.5 \mathrm{ml})$ of this extract was well mixed with $(0.5 \mathrm{ml})$ FolinCiocalteu's phenol reagent (Sigma-Aldrich, Buchs, Switzerland). A volume of $(3 \mathrm{ml})$ of $\mathrm{Na}_{2} \mathrm{CO}_{3}$ saturated solution was added to the batter and brought up to $(10 \mathrm{ml})$ with distilled wáter, and then allowed to stand for 30 minutes at room temperature. The final solution was centrifuged $(10$ minutes, $3000 \mathrm{~g})$ and the supernatant absorbance was read $(765 \mathrm{~nm})$ by the spectrophotometer (LABOMED, Los Angeles, USA). The olive pulp's total polyphenols were expressed as $\mathrm{mg}$ of gallic acid/100g of fresh fruits (Bleve et al., 2014).

\subsection{Identification of yeast isolates}

The isolated yeast from the fermented olives after 90 days of fermentation was named as Y1 and $\mathrm{Y} 2$ for the two yeast strains isolated in the 2017 season, and $\mathrm{Y} 3$ and Y4 for the two strains isolated in the 2018 season. Y1, Y2, Y3, and Y4 and the reference strain of Candida albicans ATCC 10231 were grown overnight in the YPG medium (Yeast extract 1\%: oxoid, England, peptone 2\%: oxoid, England, glucose $2 \%$ ) at 30 ${ }^{\circ} \mathrm{C}$. The manufacturer's instructions of Wizard Genomic DNA purification (Promega, Madison, WI, USA) were strictly followed in the extraction of the experimental genomic DNA. Sequencing the $5^{\prime}$ end of the 26S rDNA encompassing the D1 and $\mathrm{D} 2$ expansion domains using the primers NL1 (5'-GCATATCAATAAGGGGA GGAAAAG-3') and a reversed primer NL4 (5'-GGT CCG TGT TTC AAG ACGG-3') were then performed for the identification of experimental genomic DNA. Amplification was performed for 36 PCR cycles with annealing at $52{ }^{\circ} \mathrm{C}$, extension at $72{ }^{\circ} \mathrm{C}$ for 2 minutes, and denaturation at $94{ }^{\circ} \mathrm{C}$ for 1 minute. The products of PCR were purified and sequenced for species identification (Macrogen, Korea). The National Center for Biotechnology Information BLAST online program was used to determine the DNA sequence similarity (BLAST, 2019) and as given by Wang et al., (2008).

\subsection{In Vitro probiotic characterization of yeast}

\subsubsection{Tolerance of yeast to low $\mathrm{pH}$ and bile salt}

An overnight culture of yeast isolates was tested for viability as affected by low $\mathrm{pH}$ and bile salt. Fresh yeast culture (100 $\mu \mathrm{l}$; ca $1 \times 10^{8} \mathrm{CFU} /$ $\mathrm{ml}$ ) of each yeast isolate was inoculated in sterile test tubes containing either: $1 \mathrm{ml}$ of acidified YPG medium ( $5 \mathrm{M} \mathrm{HCl}, \mathrm{pH} 2.5), 1 \mathrm{ml}$ of YPG containing $0.1 \%$ bile salts, $1 \mathrm{ml}$ of YPG containing $0.3 \%$ bile salts, or $1 \mathrm{ml}$ of YPG alone. A viable count of yeast isolates in acidified YPG medium was measured at $0,1,2$ and 3 hours of incubation at $37^{\circ} \mathrm{C}$ by taking samples of $100 \mu$, serially diluted and plated onto YPG agar plates. Yeast isolates' survival in bile salts was measured after incubation for 24 hours at $37^{\circ} \mathrm{C}$. A yeast culture (one loopful of $2 \mathrm{~mm}$ in diameter) was streaked onto YPG agar to check viability. Yeast isolates inoculated in YPG medium alone was used as the positive control. The test was performed in duplicate (van der Aa Kuhle et al., 2005).

\subsubsection{Adhesion of yeast strains to intestinal cell lines}

The colonocyte-like cell lines Caco-2 were used to determine the adhesion ability of the yeast isolates. Caco-2 cell line was kindly supplied by Prof. Y. Bustanji of the University of Jordan. The culture and maintenance of the cell lines were carried out following standard procedures using DMEM medium High Glucose (EuroClone, Italy) supplemented with fetal bovine serum $(10 \%)$ and with a mixture of antibiotics $(10 \mathrm{U} / \mathrm{ml}$ penicillin, $10 \mu \mathrm{g} / \mathrm{ml}$ streptomycin). Intestinal cells were seeded in 24-well plates and cultivated until a confluent differentiated state was reached (monolayers). Yeasts were grown in YPG media for 48 hours at $30^{\circ} \mathrm{C}$, then $1 \mathrm{ml}$ of yeast culture was centrifuged and the pellet was washed twice with PBS solution. The yeast pellet was suspended in the DMEM media without antibiotics to reach an inoculum size of ca $\sim 10^{8} \mathrm{CFU} / \mathrm{ml}$. Cellular monolayers were also carefully washed with PBS solution, and yeast suspensions were added. Adhesion experiments were carried out for 90 minutes at $37{ }^{\circ} \mathrm{C}, 5 \% \mathrm{CO}_{2}$ and, afterward, wells were gently washed to release unattached yeasts before proceeding with the lysis of cellular monolayers using a $0.25 \%$ 
Trypsin- EDTA solution (Sigma, USA). Dilutions of samples, before and after adhesion, were made in PBS solution and yeast counts were performed on YPG agar plates. The adhesion was calculated as: \% CFU adhered yeasts/ CFU added yeasts. Experiments were carried out in two replicated plates and in each plate, two wells were used per sample (Zivkovic et al., 2015).

\subsubsection{Antimicrobial activity of yeasts}

A few common food-borne pathogens were selected, Escherichia coli (ATCC 8739), Salmonella typhimurium (02:8432), Salmonella enteridis (CRIES1016), Staphylococcus aureus (ATCC 25923) and Staphylococcus aureus (ATCC 6538P); they were cultured on Trypticase Soy Soft (TSS) agar $(20 \mathrm{~mL}$, with $8 \mathrm{~g} / \mathrm{L}$ agar; Oxoid, England). The capacity of each yeast strain to inhibit the previous bacterial pathogens was determined using the TSS agar medium. One loopful ( $2 \mathrm{~mm}$ in diameter) of yeast was streaked as a line $(2-3 \mathrm{~cm})$ onto the soft-agar surface; the plates were then incubated at $27^{\circ} \mathrm{C}$ for 24 hours and screened for inhibition zones around the bacterial colonies (Silva et al., 2011).

\subsection{Technical characteristics of yeast isolates}

The lipolytic activity of yeast isolates was qualitatively tested with $5 \%(\mathrm{v} / \mathrm{v})$ olive oil, emulsified by vigorous shaking. The plates were inoculated by streaking once across and incubated at $25{ }^{\circ} \mathrm{C}$ for 10 days. The plates were then flooded with a saturated copper sulphate solution and allowed to stand for 10 minutes. Where growth occurred, the appearance of a bluish color was taken as being indicative of positive lipolytic activity. The blue zones were intensified if the plates were kept in the refrigerator after pouring off the developer (Kurtzman et al., 2011). Catalase activity was determined by adding drops of $\mathrm{H}_{2} \mathrm{O}_{2}(3 \%)$ to the cultured colonies; the release of gas was indicative of a positive result (Silva et al., 2011).

\subsection{Statistical analysis}

The data were analyzed using the Statistical Package for Social Sciences programme version $20\left(\right.$ SPSS $\left.^{\circledR}\right)$, Chicago, Il, USA). Values are given as the mean $\pm \mathrm{SD}$. Each datum represents six replicates for each season; i.e. three sample replicates for each of the two jars each season were measured. Appropriate data were tested using the independent sample t-test for significant differences. The statistical significance level was fixed at $p<0.05$ (Issaoui et al., 2011)

\section{RESULTS}

\subsection{Microbiological Characteristics of fermented olives}

After 3 months of olive fermentation, yeast was the predominantly isolated microorganism from the olive samples. As shown in Figure 1, the yeast count reached its highest level after 2 months of fermentation (ca $3 \times 10^{4} \mathrm{CFU} /$ gram olive in the 2017 season). A significant ( $p=0.004)$ reduction in yeast count was detected by the end of the third month compared to the yeast count during the second month. The $\mathrm{pH}$ of the brine measured at zero time fermentation was 5.2. $\mathrm{pH}$ values and were significantly $(p=0.001)$ reduced after 60 days of fermentation $(\mathrm{pH}=4.45$ in season 2017, $\mathrm{pH}=4.26$ in season 2018) compared to values after 30 days of fermentation (Figure 1). At the start of fermentation, the brine concentration was $100 \mathrm{~g} / \mathrm{L}$. It markedly $(\mathrm{p}=0.001)$ decreased after 30 days of fermentation $(90 \mathrm{~g} / \mathrm{L}$ in season 2017 and $91 \mathrm{~g} / \mathrm{L}$ in season 2018). A further, but stable drop in this variable, was noticed from 60 days till the end of fermentation (89 and $86 \mathrm{~g} / \mathrm{L}$ for in the two seasons, respectively). In the 2018 season, lower yeast counts were detected after 3 months of fermentation compared to the yeast count in the 2017 season; the yeast count reached $\mathrm{ca} \sim 5 \times 10^{2} \mathrm{CFU} / \mathrm{g}$ olives on the $30^{\text {th }}$ day, $8.8 \times 10^{3} \mathrm{CFU} / \mathrm{g}$ olives on the $60^{\text {th }}$ day and $7.8 \mathrm{x}$ $10^{3} \mathrm{CFU} / \mathrm{g}$ olives on the $90^{\text {th }}$ day of fermentation. By the end of 90 days of fermentation, the LAB was not detected at any level. Figure 1 clarifies the dynamics between yeast count and $\mathrm{pH}$ values during the olive fermentation process.

\subsection{Proximate composition and total polyphenols in fermented olives}

The analysis of proximate composition of fermented green Nabali Baladi olives revealed a high content in oil (19\% wet weight). Table 1 shows the detailed proximate composition analysis results for fermented olive samples taken from 2 separate jars in two different seasons. The results of the two seasons' analysis were comparable. Crude fiber content was $3 \mathrm{~g} / 100 \mathrm{~g}$ edible part of olives. A low amount of protein was 
detected in fermented olives $(0.9 \mathrm{~g} / 100 \mathrm{~g}$ edible part). The total polyphenol content in green Nabali Baladi olives ranged from 290-310 mg gallic acid equivalent/100g of fermented green olive pulp (Table 1).

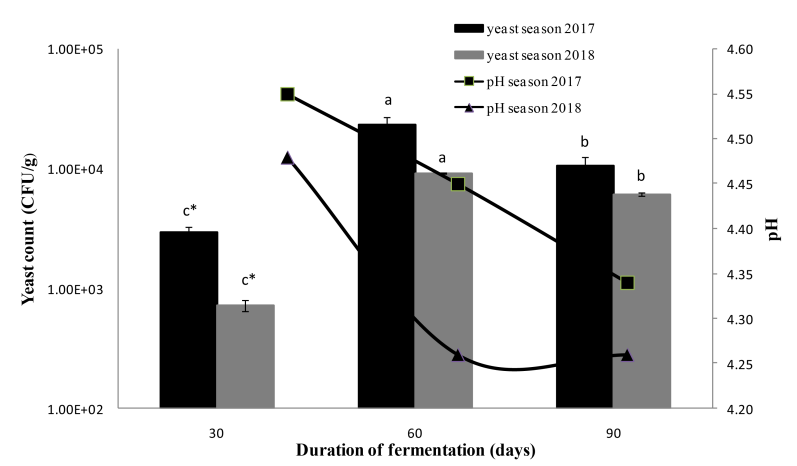

FigURE 1. Viable count of yeasts (CFU/g) and brine $\mathrm{pH}$ changes during green Nabali Baladi olive fermentation.

Lactic acid bacteria were not detected during 90 days of the experiment. Values are given as mean $\pm \mathrm{SD}$ (Based on three samples replicaes for each of the two jars each season; i.e. six replicates for each season). Independent sample t-test was used. Bars with different superscripts are significantly different $(\mathrm{p}<0.05)$. $*$ Significantly different $(\mathrm{p}<0.05)$ in the same time duration.

\subsection{Fatty acid composition of fermented olives}

Table 2 presents the fatty acid composition of green Nabali Baladi fermented olives. Oleic acid was the major fatty acid (about $70 \%$ of total fatty acids). Other fatty acids such as palmitic acid, linoleic acid and stearic acid account for about $25 \%$ of the total fatty acids. Total saturated fatty acids compose $17 \%$ of the fatty acid, whereas total polyunsaturated fatty acids were only $9 \%$.

\subsection{Identification of yeast isolates}

The identification of yeast isolates (Y1, Y2, $\mathrm{Y} 3$, and $\mathrm{Y} 4$ ) was performed by the sequencing of the 26S rDNA encompassing the D1/D2 expansion domains. BLAST identified the two DNA sequences as Candida diddensiae, Candida naeodendra strain MB14804, Candida diddensiae, and Candida diddensiae as $100 \%$, $99 \%, 99 \%$, and $99 \%$, respectively (Table 3).

\subsection{In Vitro probiotic characterization of yeast}

\subsubsection{Tolerance to low $\mathrm{pH}$ and bile salt and adhesion to intestinal cell lines}

Table 3 shows the results of Y1, Y2, Y3 and Y4 in vitro probiotic characteristics testing. $\mathrm{Y} 1$ showed higher tolerance to $\mathrm{HCl}$ than $\mathrm{Y} 2$. On another hand, isolates $\mathrm{Y} 3$ and $\mathrm{Y} 4$ isolated in the second season had comparable tolerance to acidic media. Collectively, ca $\sim 10^{7} \mathrm{CFU} / \mathrm{ml}$ of yeasts were able to survive acidic conditions after $3 \mathrm{hr}$ of incubation. In addition, all yeast isolates showed comparable tolerance to bile salt at different concentrations $(0.1$ and $0.3 \%)$. Y1, Y2, Y3, and Y4 also showed high adhesion ability to Caco-2 cell line, ca $\sim 10^{7} \mathrm{CFU}$ of yeast isolates were able to attach to intestinal cell lines after $90 \mathrm{~min}$ of incubation. $\mathrm{Y} 3$ and $\mathrm{Y} 4$ had higher adhesion ability to the Caco-2 cell line than Y1 and Y2, but it was considered low adhesion ability (Table 3 ).

TABLE 1. Proximate composition analysis of fermented green Nabali Baladi olives per $100 \mathrm{~g}$ of edible part ${ }^{1-4}$

\begin{tabular}{lcc}
\hline \multirow{2}{*}{ Nutrient } & \multicolumn{2}{c}{ g/ 100 g of edible part } \\
\cline { 2 - 3 } & Season 2017 & Season 2018 \\
\hline Moisture & $67.9^{\mathrm{a}} \pm 0.3^{\mathrm{a}}$ & $67.5 \pm 0.6^{\mathrm{a}}$ \\
Fat & $19.27 \pm 0.4^{\mathrm{a}}(60.0 \pm 0.3)$ & $19.83 \pm 0.2^{\mathrm{a}}(61.0 \pm 0.2)$ \\
Carbohydrate & $4.9 \pm 0.6^{\mathrm{a}}(15.26 \pm 1.2)$ & $4.3 \pm 0.4^{\mathrm{a}}(13.2 \pm 0.3)$ \\
Crude Protein & $0.9 \pm 0.05^{\mathrm{a}}(2.8 \pm 0.3)$ & $0.9 \pm 0.02^{\mathrm{a}}(2.8 \pm 0.3)$ \\
Crude Fiber & $3.0 \pm 0.1^{\mathrm{a}}(9.5 \pm 0.7)$ & $3.13 \pm 0.06^{\mathrm{a}}(10.2 \pm 0.1)$ \\
Ash & $4.1 \pm 0.1^{\mathrm{a}}(12.5 \pm 1.9)$ & $4.2 \pm 0.1^{\mathrm{a}}(12.9 \pm 1.3)$ \\
Total & $306.3 \pm 42.3^{\mathrm{a}}$ & $295.4 \pm 14.6^{\mathrm{a}}$ \\
Polyphenols* & $(954.2 \pm 130.8)$ & $(908.9 \pm 45.5)$ \\
\hline
\end{tabular}

1. Edible part of fermented olive is $75.27 \mathrm{~g} / 100 \mathrm{~g}$ of whole olives 2. Values between parenthesis are calculated based on dry weight 3. Values are given as mean $\pm \mathrm{SD}$ (Based on three samples replicates for each of the two jars each season; i.e. six replicates for each season). Independent sample t-test was used.

4. Values with different superscripts within the same row are significantly different $(\mathrm{p}<0.05)$

*Total polyphenols was expressed as $\mathrm{mg}$ of gallic acid/100 $\mathrm{g}$ edible olive

\subsubsection{Antimicrobial activity of yeasts}

The yeast isolates (Y1, Y2, Y3, and Y4) did not show any inhibition zone surrounding their colonies in the antimicrobial tests, which indicated that the isolates did not have antimicrobial activity against the selected pathogenic bacteria.

\subsection{Technical characteristics of yeast isolates}

Yeast isolates were tested for lipase and catalase production. They were found negative for lipase production and positive for catalase (Table 3 ). 
TABLE 2. Fatty acid composition of oil extracted from fermented olives ${ }^{1,2}$

\begin{tabular}{|c|c|c|}
\hline \multirow{2}{*}{ Fatty acid } & \multicolumn{2}{|c|}{$\mathrm{g} / \mathrm{100} \mathrm{g}$ of total fatty acid } \\
\hline & Season 2017 & Season 2018 \\
\hline C 16:0 & $14.3 \pm 0.06^{\mathrm{a}}$ & $14.3 \pm 0.06^{\mathrm{a}}$ \\
\hline C $16: 1$ & $1.5 \pm 0.02^{\mathrm{a}}$ & $1.6 \pm 0.02^{a}$ \\
\hline C $18: 0$ & $2.6 \pm 0.08^{\mathrm{a}}$ & $2.6 \pm 0.08^{a}$ \\
\hline C $18: 1$ & $70.6 \pm 0.3^{a}$ & $69.8 \pm 0.3^{\text {a }}$ \\
\hline C $18: 2$ & $8.2 \pm 0.1^{\mathrm{a}}$ & $8.2 \pm 0.1^{\mathrm{a}}$ \\
\hline C $18: 3$ & $0.73 \pm 0.02^{\text {a }}$ & $0.74 \pm 0.02^{\mathrm{a}}$ \\
\hline C $20: 0$ & $0.4 \pm 0.01^{\mathrm{a}}$ & $0.4 \pm 0.01^{\text {a }}$ \\
\hline C $20: 1$ & $0.23 \pm 0.01^{\mathrm{a}}$ & $0.22 \pm 0.01^{\mathrm{a}}$ \\
\hline $\mathrm{C} 22: 0$ & $0.1 \pm 0.01^{\mathrm{a}}$ & $0.1 \pm 0.01^{\text {a }}$ \\
\hline$\Sigma$ SFA & 17.4 & 17.3 \\
\hline$\Sigma$ MUFA & 72.33 & 71.57 \\
\hline$\Sigma$ PUFA & 8.94 & 8.89 \\
\hline
\end{tabular}

1. Values are given as mean \pm SD (Based on three sample replicates for each of the two jars each season; i.e. six replicates for each season). Independent sample t-test was used.

2. Values with different superscripts within the same row are significantly different $(\mathrm{p}<0.05)$

\section{DISCUSSION}

The Nabali Baladi olive is one of the major local olive varieties in Jordan; it is widely used for fermentation and oil production (Humeid et al., 1991). A limited number of studies investigated the qualitative characteristics of fresh Nabali Baladi olives with an emphasis on oil production purposes. To our knowledge, this is the first study investigating the nutritional, functional and microbiological characteristics of fermented green Nabali Baladi olives in Jordan.

The results demonstrated that the oil content of fermented olives ranged from 19-20\% (wet weight) of flesh ( $60 \%$ based on dry weight) after 3 months of fermentation in two different seasons (2017 and 2018). It has been reported that the oil content of ripened Nabali Baladi olives without fermentation was $60 \%$ of flesh dry weight in Jordan (Al-Ismail et al., 2011) and 55\% (dry weight) in Palestine (Ebiad and Abu-Qaoud, 2014). These results are comparable to those of the present study. However, the oil content of fermented green olives is widely variable depending on the olive variety. In Tunisia, one of the major olive producer in the region, the oil content of green table olives ranged from $29 \%$ (dry weight) in the Sayali olive variety (Sakouhi et al., 2008) to $35 \%$ (dry weight) in the Meski olive variety (Issaoui et al., 2011). Moreover, Turkish olive varieties such as the Domat cultivar had low oil content amounting to $23 \%$ based on dry weight (Savas and Uylaser, 2013), while Gemlike and Edincik varieties had high oil content reaching 38 and $50 \%$, based on dry weight, respectively (Borcakli et al., 1993). High oil content ( $68 \%$ of dry pulp) was found in the Italian Intosso d'Abruzzo cultivar table olives (Lanza et al., 2010). Accordingly, Nabali Baladi olives can be considered a rich source of oil before and after fermentation compared to other olive varieties in the region.

In this study, it was demonstrated that $100 \mathrm{~g}$ of edible fermented green Nabali Baladi olives contained $0.9 \mathrm{~g}$ protein, $4.6 \mathrm{~g}$ carbohydrate and $3 \mathrm{~g}$ of crude fiber. Similar to our results, the Italian green Intosso d'Abruzzo fermented olives were found to contain $1 \mathrm{~g}$ protein, $2.6 \mathrm{~g}$ fiber and $2.8 \mathrm{~g}$ carbohydrates in $100 \mathrm{~g}$ fermented olives (Lanza et al., 2010). However, it has been documented that the olive fresh fruit's average composition includes water $(50 \%)$, protein $(1.6 \%)$, oil $(22 \%)$, carbohydrate $(19.1 \%)$ and cellulose $(5.8 \%)$ (Ghanbari et al., 2012).

Indeed, the analysis of fatty acid profile in Nabali Baladi olive oil revealed that oleic acid is the main fatty acid followed by palmitic acid and linoleic acid (70, 14.3 and 8.3\%, respectively). It was found that olive processing and fermentation did not cause any significant changes in the fatty acid profile; instead, the fatty acid profile was dependent on olive varieties (López-López et al., 2015). Previous studies analyzed the fatty acid profile of olive oil extracted from Nabali Baladi olives cultivated in different regions of Jordan and Palestine and the results were highly variable (Humeid et al., 1991; Al-Ismail et al., 2011; Ebiad and Abu-Qaoud, 2014). It was found that oleic acid accounted for $67 \%$ of the oil extracted from Nabali Baladi olives collected from Bani Kenaneh in north Jordan, followed by linoleic acid (14\%) and palmitic acid (12.5\%) (Al-Ismail et al., 2011). Oleic acid represented (66\%) of total fatty acids in the oil extracted from Nabali Baladi olives in Palestine, followed by palmitic acid (15\%) and linoleic acid (12.8\%) (Ebiad and AbuQaoud 2014). On another hand, oleic acid represented a higher percentage (73-76\%) and lower linoleic acid (8.5-9.7\%) and palmitic acid $(8.8-11.8 \%)$ in oil extracted from Nabali Baladi olives collected from Amman, Jordan (Humeid et al., 1991). As in olive oil, fermented green Nabali Baladi olives are a valuable source of 
TABLE 3. Yeast identification, $\mathrm{HCl}(\mathrm{pH}$ 2.5) and bile salt tolerance, adhesive ability and technical characteristics for the yeast isolates from fermented green Nabali Baladi olives

\begin{tabular}{|c|c|c|c|c|c|c|c|c|c|c|}
\hline & \multirow{3}{*}{$\begin{array}{l}\text { Identification by } \\
\text { sequencing }\end{array}$} & \multirow{3}{*}{ Identity (\%) } & \multicolumn{4}{|c|}{ Viability of yeast } & \multirow{2}{*}{\multicolumn{2}{|c|}{$\frac{\text { Adhesion ability CFU/ml }}{\text { Time (min) }}$}} & \multicolumn{2}{|c|}{ Technical characteristics } \\
\hline & & & \multicolumn{2}{|c|}{$\mathrm{HCl}(\mathrm{pH} 2.5) \mathrm{CFU} / \mathrm{ml}$} & \multicolumn{2}{|c|}{ Bile salt (\%) } & & & \multirow[t]{2}{*}{ Lipase } & \multirow[t]{2}{*}{ Catalase } \\
\hline & & & $\mathbf{0 ~ h}$ & $3 \mathrm{~h}$ & 0.1 & 0.3 & $\mathbf{0}$ & 90 & & \\
\hline Y1 & Candida diddensiae & 100 & $1.07 \times 10^{8} \pm 2 \times 10^{7}$ & $5.9 \times 10^{7} \pm 1.5 \times 10^{6}$ & $+*$ & + & $1.6 \times 10^{8} \pm 3.1 \times 10^{7}$ & $3.5 \times 10^{7} \pm 1.1 \times 10^{6}$ & - & + \\
\hline $\mathrm{Y} 2$ & $\begin{array}{l}\text { Candida naeodendra strain } \\
\text { MB14804 }\end{array}$ & 99 & $3.25 \times 10^{7} \pm 4.1 \times 10^{6}$ & $9.49 \times 10^{6} \pm 6.1 \times 10^{5}$ & + & + & $3.9 \times 10^{8} \pm 1.1 \times 10^{7}$ & $6.32 \times 10^{7} \pm 2.2 \times 10^{6}$ & - & + \\
\hline Y3 & Candida diddensiae & 99 & $5.35 \times 10^{7} \pm 5 \times 10^{6}$ & $2.43 \times 10^{7} \pm 3.6 \times 10^{6}$ & + & + & $1.35 \times 10^{8} \pm 5.2 \times 10^{7}$ & $4.34 \times 10^{7} \pm 1.6 \times 10^{6}$ & - & + \\
\hline Y4 & Candida diddensiae & 99 & $6.25 \times 10^{7} \pm 2.5 \times 10^{6}$ & $3.2 \times 10^{7} \pm 2 \times 10^{6}$ & + & + & $2.5 \times 10^{8} \pm 6.5 \times 10^{7}$ & $7.68 \times 10^{7} \pm 9.2 \times 10^{5}$ & - & + \\
\hline
\end{tabular}

*+ No inhibitions were observed compared to the control

Values are given as mean $\pm \mathrm{SD}$ (Based on three sample replicates for each of the two jars each season i.e. six replicates for each season).

monounsaturated fatty acids (oleic acid), which is considered one of the health benefits of olives and olive oil (Ghanbari et al., 2012).

Fermented olives have a wide range of functional properties besides high oil and oleic acid contents. Olive fruits are considered a rich source of polyphenols and other bioactive compounds (Ghanbari et al., 2012). A clinical study demonstrated that olive intake increases polyphenols and total antioxidant potential in plasma, thus indicating that olive polyphenols have good bioavailability (Kountouri et al., 2007). In this study, the total polyphenol content in green Nabali Baladi olives was found to be moderate (300 mg gallic acid equivalent/100 g). Previous studies showed highly variable total polyphenol contents in fermented olives. The Italian green Intosso d'Abruzzo fermented olive total polyphenol content was $167 \mathrm{mg}$ caffeic acid equivalent /100 g (Lanza et al., 2010). In Tunisia, green Meski fermented olives contained $1170 \mathrm{mg}$ hydroxytyrosol equivalent/100 g (Issaoui et al., 2011). However, the total polyphenol content in fermented green olives has been reported to be dependent on olive variety, time of harvest and treatment method (Othman et al., 2009; Bouaziz et al., 2010). As is well known, the debittering step in olive fermentation reduces the polyphenol content, mainly oleuropein, by either dilution or chemical hydrolysis (Issaoui et al., 2011). The total polyphenol content in the green Chetoui olive variety was decreased by $58 \%$ after spontaneous fermentation for 67 days (Othman et al., 2009). Polyphenol content was increased from 346 to $576 \mathrm{mg}$ gallic acid equivalent $/ 100 \mathrm{~g}$ in green Chetoui olives during 1 month of tree maturation (Bouaziz et al., 2010). Moreover, it was found that olive varieties with small drupe size have a higher quantity of oleuropein (Morello et al., 2005). Green Nabali Baladi olives have a large fruit size and high oil content (Al-Ismail et al., 2011), thus they are expected to have low total polyphenol content compared to other olive varieties.

Upon fermentation, olives became a rich source of beneficial microorganisms including $\mathrm{LAB}$ and yeasts (Aponte et al., 2010; Hurtado et al., 2012; Argyri et al., 2013). Different isolates of LAB and yeasts were found to possess probiotic properties in vitro (Van der Aa Kuhle et al., 2005, Zivkovic et al., 2015). Traditional fermentation methods vary among countries; the Spanish-style green olives are characterized by treatment with $\mathrm{NaOH}$ before the addition of brine (brine concentration usually ranges between $6-8 \% \mathrm{w} / \mathrm{v}$ ) and starter culture may be added (Abriouel et al., 2011). Green olive fermentation according to the Sicilian method is characterized by repeated washing of the olives with water as a debittering mechanism and brining in a $6-10 \%$ salt solution (Aponte et al., 2010). The Turkish traditional method uses either scratched or cracked green olives which are first placed in water to reduce bitterness and then transferred to the fermentation tanks where the brine-to-salt ratio is increased progressively and reaches 5-6\% (Cillidag, 2013). Two famous traditional olive fermentation methods are reported in Tunisia. The first is a simple process and consists of a modest addition of a balanced amount of water and salt to the olive fruits that must be harvested unripe and kept in jars made of clay or glass (Issaoui et al., 2011). The second process is the oldest and consists of adding oil and salt to the olive fruits which must be kept in a fabric bag with a large opening. In the latter method, olives ripen faster and lose their color rapidly due to direct contact with air and temperature (Issaoui et al., 2011). 
In Jordan, the traditional fermentation method is characterized by debittering olive fruit through soaking in water for three days followed by spontaneous fermentation in brine $(>10 \% \mathrm{w} / \mathrm{v}$ of raw salt) under low-temperature conditions (NCARE, 2000). Vegetable fermentation is a natural and spontaneous process that is achieved through the activity of indigenous microbiota, particularly $\mathrm{LAB}$ and yeast on the raw material (Bautista-Gallego et al., 2011). It is well documented that LAB is the leading microorganism in different vegetable fermentations including olives (Aponte et al., 2010, Hurtado et al., 2012). However, olive fermentation could be affected by different factors that would encourage specific microorganisms to dominate the fermentation process such as brine concentration, olive variety, previous alkali treatment and temperature during the fermentation process. Most green olive fermentations are dominated by LAB species (Hurtado et al., 2012). Previous studies revealed that the Spanish-style treated olive fermentation is due to $\mathrm{LAB}$, whereas black olives were fermented primarily by yeasts, and $\mathrm{LAB}$ represents a small proportion of the total microflora (Aponte et al., 2010).

Indeed, our results showed that green Nabali Baladi olive fermentation was dominated by yeast throughout the 90 days of fermentation. The identification of isolated yeasts by sequencing of the $\mathrm{D} 1 / \mathrm{D} 2$ region of the $26 \mathrm{~S}$ rDNA region revealed that Candida diddensiae and Candida naeodendra were the predominant yeasts in the green Nabali Baladi fermented olives. High brine concentrations and low $\mathrm{pH}$ values at the start of fermentation would favor yeast growth and inhibit lactic acid bacteria. When brine concentration was maintained above $80 \mathrm{~g} / \mathrm{L}$, yeast growth dominated the black olive fermentation for 90 days (Bleve et al., 2014). In this study, the brine concentration started at $100 \mathrm{~g} / \mathrm{L}$ and ended at $86 \mathrm{~g} / \mathrm{L}$ after 90 days of fermentation. Furthermore, the fermentation of green cracked olives in brine concentrations $(90-110 \mathrm{~g} / \mathrm{L})$ was dominated by yeast for 6 months of fermentation with little or no lactic acid bacteria growth (Abriouel et al., 2011).

Nevertheless, different yeast species were isolated from fermented green and black olives. Green Sicilian olive fermentation was dominated by Candida parapsilosis, Pichia guilliermondii, and Pichia kluyveri (Aponte et al., 2010). The exploration of the biological diversity of yeasts in the mass fermentation activities of green table olives in Spain revealed that Candida diddensiae, Saccharomyces cerevisiae, and Pichia membranifaciens were the most abundant yeast species directly isolated from brined Aloreña olives; whereas for Gordal and Manzanilla cultivars, they were Candida tropicalis, Pichia galeiformis and Wickerhamomyces anomalus. In the case of Gordal and Manzanilla green olives which were prepared according to the Spanish method, the prevailing yeasts were Debaryomyces etchellsii, C. tropicalis, $P$. galeiformis, and Kluyveromyces lactis (Bautista-Gallego et al., 2011). Candida naeodendra is a species of the Candida diddensiae group that has been frequently identified in olive fermentation processes (Bautista-Gallego et al., 2011). Moreover, different strains of Candida diddensiae were shown to produce a wide range of lipase, esterase or $\beta$-glucosidase activities that qualify them to be used as a potential starter in olive fermentation (Ciafardini and Zullo, 2015).

On the other hand, the probiotic characteristics of the Candida species have been scarcely studied. However, strains of yeasts isolated from fermented olives can have some beneficial criteria that may improve the technical and functional properties of fermented olives (Hatoum et al., 2012). Accordingly, Candida diddensiae and Candida naeodendra were tested for their acid and bile tolerance and adhesion to intestinal cell lines in vitro. The results presented in Table 3 demonstrate that the two isolates can tolerate gastric conditions and potentially survive in the gastrointestinal tract. Neither isolate showed antimicrobial activities against a group of pathogenic bacteria. It is possible that yeast isolates have positive immunomodulatory activity as documented previously (Smith et al., 2014). In essence, the isolated yeasts were positive for catalase production. This character is important for olive preservation due to its high content of unsaturated fatty acids; in fact, it is, therefore, possible to effectively prevent oxidation and peroxide formation (Silva et al., 2011).

\section{CONCLUSIONS}

Fermented green Nabali Baldi olives are a rich source of oleic acid, polyphenols, and dietary fiber. The fermentation of green Nabali Baladi olives according to the traditional fermentation method in Jordan is dominated by yeast strains, primarily Candida diddensiae, with no detection of LAB.This yeast strain can tolerate HCL and 
bile salt and has a medium ability of adhesion to intestinal cell lines. Thus, $C$. diddensiae isolated from fermented green Nabali Baladi olives may represent a good probiotic candidate. In this respect, further in vitro and in vivo studies are required.

\section{ACKNOWLEDGMENTS}

This study was supported by the Deanship of Scientific Research, The University of Jordan.

\section{REFERENCES}

Association of the Official Analytical Chemists (AOAC). 1995. Official Methods of Analysis. Arlington, Virginia, USA.

Abriouel H, Benomar N, Lucas R ,Galvez A. 2011. Culture-independent study of the diversity of microbial populations in brines during fermentation of naturally-fermented Aloreña green tableolives. Int. J. Food Microbiol. 144, 487-96. https://doi.org/10.10 16/j.ijfoodmicro.2010.11.006

Al-Ismail KM, Ahmad R, Al-Dabbas M, Ajo RY, Rababah T. 2011. Some physiochemical properties of olive and olive oil of three jordanian olive varieties. Riv. Ital. Sostanze Grasse 88, 191-198.

Aponte M, Ventorino V, Blaiotta G, Volpe G, Farina V, Avellone G, Lanza CM, Moschetti G. 2010. Study of green Sicilian table olive fermentations through microbiological, chemical and sensory analyses. Food Microbiol. 27, 162-70. https://doi.org/10.1016/ j.fm.2009.09.010

Argyri AA, Zoumpopoulou G, Karatzas KA, Tsakalidou E, Nychas GJ, Panagou EZ, Tassou CC. 2013. Selection of potential probiotic lactic acid bacteria from fermented olives by in vitro tests. Food Microbiol. 33, 282-291. https://doi.org/10.1016/j.fm.2012.10.005

Bautista-Gallego J, Rodriguez-Gomez F, Barrio E, Querol A, Garrido-Fernandez A, ArroyoLopez FN. 2011. Exploring the yeast biodiversity of green table olive industrial fermentations for technological applications. Int. J. Food Microbiol. 147, 89-96. https:// doi.org/10.1016/j.ijfoodmicro.2011.03.013

BLAST: Basic Local Alignment Search Tool. Last retrieved, September 2019. https:// blast.ncbi.nlm.nih.gov/Blast.cgi

Bleve G, Tufariello M, Durante M, Perbellini E, Ramires FA, Grieco F, Cappello MS, De
Domenico S, Mita G, Tasioula-Margari M, Logrieco AF. 2014. Physico-chemical and microbiological characterization of spontaneous fermentation of Cellina di Nardò and Leccino table olives. Front. Microbiol. 5, 570. https://doi.org/10.3389/fmicb.2014.00570

Borcakli M, Özay G, Alperden I, Özsan E, Erdek Y. 1993. Changes in chemical and microbiological composition of two varieties of olive during fermentation. Grasas Aceites 44, 253-258. https://doi.org/10.3989/gya.1993. v44.i4-5.1075

Bouaziz M, Jemai H, Khabou W, Sayadi S. 2010. Oil content, phenolic profiling and antioxidant potential of Tunisian olive drupes. J. Sci. Food Agric. 90, 1750-1758. https://doi.org/10.1002/ jsfa.4013

Ciafardini G, Zullo BA. 2015. Effect of lipolytic activity of Candida adriatica, Candida diddensiae and Yamadazyma terventina on the acidity of extra-virgin olive oil with a different polyphenol and water content. Food Microbiol. 47, 12-20. https://doi.org/10.1016/j.fm.2014. 10.010

Cillidag S. 2013. Table olive processing technologies. Options Méditerranéennes. Séries A: Mediterranean Seminars. CIHEAMIAMZ; IOC, International Olive Council.

Ebiad R,Abu-Qaoud H. 2014. Morphological and biochemical characterization of three olive" Oleaeuropaea L." cultivars in Palestine. Jordan J. Agric. Sci. 10, 130-143.

Food and Drug Adiminstration. Bacteriological Analytical Manual on line. 2001. http:// www.fda.gov/Food/FoodScienceResearch/Lab oratoryMethods/ucm2006949.htm

Ghanbari R, Anwar F, Alkharfy KM, Gilani AH, Saari N. 2012. Valuable nutrients and functional bioactives in different parts of olive (Olea europaea L.)-A review. Int. J. Mol. Sci. 13, 3291-340. https://doi.org/10.3390/ijms 130 33291

Hatoum R, Labrie S, Fliss I. 2012. Antimicrobial and probiotic properties of yeasts: from fundamental to novel applications. Front. Microbiol. 3, 421. https://doi.org/10.3389/fmi cb.2012.00421

Humeid MA, Takruri HR, Daqqaq RF. 1991. Nabali olive oil ripening and oil properties. Nutr. Health. 7, 151-154. PMID: 1923072

Hurtado A, Reguant C, Bordons A, Rozes N. 2012. Lactic acid bacteria from fermented table olives. Food Microbiol. 31, 1-8. https://doi.org/ 10.1016/j.fm.2012.01.006 
Issaoui M, Dabbou S, Mechri B, Nakbi A, Chehab H, Hammami M. 2011. Fatty acid profile, sugar composition, and antioxidant compounds of table olives as affected by different treatments. Eur. Food Res.Tech. 232, 867-876. https://doi.org/10.1007/s00217-011-1 455-3

Kountouri A, Mylona A, Kaliora A, Andrikopoulos N. 2007. Bioavailability of the phenolic compounds of the fruits (drupes) of Olea europaea (olives): impact on plasma antioxidant status in humans. Phytomedicine 14, 659-667. https://doi.org/10.1016/j.phymed. 2007.06.001

Kurtzman CP, Fell JW, Boekhout T, Robert V. 2011. Methods for isolation, phenotypic characterization and maintenance of yeasts. The yeasts, a taxonomic study, 5th edn. Elsevier, Amsterdam , 87-110.

Lanza B, Di Serio MG, Iannucci E, Russi F, Marfisi P. 2010. Nutritional, textural and sensorial characterisation of Italian table olives (Olea europaea L. cv. 'Intosso d'Abruzzo'). Int. J. Food Sci. Tech. 45, 67-74. https://doi.org/ 10.1111/j.1365-2621.2009.02104.x

López A, Garrido A, Montaño A. 2007. Proteins and aminoacids in table olives: relationship to processing and commercial presentation. It. J. Food Sci. 19, 217-228.

López A, García P, Garrido A. 2008. Multivariate characterization of table olives according to their mineral nutrient composition. Food Chem. 106, 369-378.

Lopez-Lopez A, Cortes-Delgado A, GarridoFernandez A. 2015. Effect of green Spanishstyle processing (Manzanilla and Hojiblanca) on the quality parameters and fatty acid and triacylglycerol compositions of olive fat. Food Chem. 188, 37-45. https://doi.org/10.1016/ j.foodchem.2015.04.080

Ministry of Agriculture (MOA). Agricultural Statistical Yearbook. 2016. Amman, Jordan.

Morelló JR, Vuorela S, Romero MP, Motilva MJ, Heinonen M. 2005. Antioxidant activity of olive pulp and olive oil phenolic compounds of the Arbequina cultivar. J. Agric. Food Chem. 53, 2002-2008. https://doi.org/10.1021/jf0483 $86 \mathrm{a}$

National Center of Agricultural Research and Education (NCARE). 2000. Pickled Green Olive Production. Publication of NCARE no 62. Amman, Jordan.

Othman NB, Roblain D, Chammen N, Thonart P, Hamdi M. 2009. Antioxidant phenolic compounds loss during the fermentation of Chétoui olives. Food Chem. 116, 662-669. https://doi.org/10.1016/j.foodchem.2009.02.08 4

Pino A, De Angelis M, Todaro A, Van Hoorde K, Randazzo CL, Caggia C. 2018. Fermentation of Nocellara Etnea table olives by functional starter cultures at different low salt concentrations. Front. Microbiol. 9. https:// doi.org/10.3389/fmicb.2018.0112

Saibandith B, Spencer JPE, Rowland IR, Commane DM. 2017. Olive polyphenols and the metabolic syndrome. Molecules 22, E1082. https://doi.org/10.3390/molecules22071082

Sakouhi F, Harrabi S, Absalon C, Sbei K, Boukhchina S, Kallel H. 2008. $\alpha$-Tocopherol and fatty acids contents of some Tunisian table olives (Olea europea L.): changes in their composition during ripening and processing. Food Chem. 108, 833-839. https://doi.org/ 10.1016/j.foodchem.2007.11.043

Savas E, Uylaser V. 2013. Quality improvement of green table olive cv.'domat' (Olea europaea L.) grown in Turkey using different debittering methods. Notulae. Botanicae Horti. Agrobotanici. Cluj-Napoca. 41, 269

Silva T, Reto M, Sol M, Peito A, Peres CM, Peres C, Malcata FX. 2011. Characterization of yeasts from Portuguese brined olives, with a focus on their potentially probiotic behavior. LWT-Food Sci. Tech. 44, 1349-1354. https:// doi.org/10.1016/j.lwt.2011.01.029

Smith IM, Christensen JE, Arneborg N, Jespersen L. 2014. Yeast modulation of human dendritic cell cytokine secretion: an in vitro study. PloS One 9, e96595. https://doi.org/10.1371/journa 1.pone.0096595

van der Aa Kuhle A, Skovgaard K, Jespersen L. 2005. In vitro screening of probiotic properties of Saccharomyces cerevisiae var. boulardii and food-borne Saccharomyces cerevisiae strains. Int. J. Food Microbiol. 101, 29-39. https:// doi.org/10.1016/j.ijfoodmicro.2004.10.039

Wang SY, Chen HC, Liu JR, Lin YC, Chen MJ. 2008. Identification of yeasts and evaluation of their distribution in Taiwanese Kefir and Viili starters. J. Dairy Sci. 91, 3798-805. https:// doi.org/10.3168/jds.2007-0468

Zivkovic M, Cadez N, Uroic K, Miljkovic M, Tolinacki M, Dousova P, Kos B, Suskovic J, Raspor P, Topisirovic L, Golic N. 2015. Evaluation of probiotic potential of yeasts isolated from traditional cheeses manufactured in Serbia and Croatia. J. Intercult. Ethnopharmacol. 4, 12-8. 